\title{
El derecho procesal durante el reinado de los Reyes Católicos y su reflejo en «Fuenteovejuna»
}

\author{
Marino de la Llana Vicente
}

\section{RESUMEN}

El presente trabajo versa sobre los aspectos jurídicos y procesales que figuran en la obra «Fuenteovejuna»,

vistos desde el sistema normativo vigente bajo el reinado de los Reyes

Católicos, periodo en el cual se desarrollan los acontecimientos, $y$ en

el que nos encontramos con una

Administración de Justicia en cuya cúspide figura la Justicia del Rey, y en el plano inferior conviven la Jurisdicción Ordinaria con sus distintos órganos y las Jurisdicciones Especiales, destacando entre ellas la que ejercen las Ordenes Militares $y$ más concretamente la Orden de Calatrava y su Maestre. En los hechos relatados en dicha obra puede observarse la particularidad con la que las normas jurídicas eran entendidas y burladas, y como la sociedad de la época reaccionaba contra determinados abusos, tomando primero la justicia por su propia mano

\section{ABSTRACT}

This report deals with the juridical and procedural aspects contained in the theatre play "Fuenteovejuna", considering the legality in force during the Catholics Kings kingdom, the period in which the action took place, and where we find a Judicial Administration organized with the King's Justice on the top and, in a less important level, the General Jurisdiction with its different organs and the Special Jurisdictions, giving importance among them, the practice of the Military Orders, in particular, the Order of Calatrava and his Grand Master. It can be observed in this play the peculiarities of how the law was understood and finally non fulfilled; and how people reacted against certain abuses, taking first the law into one's own hands and after appealing the King's Justice.

\footnotetext{
* Profesor Tutor de Derecho Procesal de la UNED.
} 
y apelando después para la solución

del proceso a la Justicia del Rey.

\section{INTRODUCCIÓN}

El estudio de las nociones jurídicas que aparecen en la obra "Fuente Ovejuna» de F. Lope de Vega no puede desligarse del estudio del sistema de derecho imperante en el reinado de los Reyes Católicos, ya que aunque la obra fue escrita en 1609, la acción se desarrolla a finales del siglo $x \vee$ y más exactamente en 1476 en una sociedad conflictiva, con la nobleza castellana dividida, el choque entre la vieja ideología feudal y la naciente ideología que sostenía la necesidad de construir una monarquía fuerte e incluso subyace un conflicto de carácter internacional, derivado del hecho de que una de las aspirantes al trono estuviera casada con el rey de Portugal.

En este conflicto ocupan una posición especialmente delicada las órdenes religioso-militares, como la de Calatrava, que también tenían estructura feudal y que a menudo se habían enfrentado a los soberanos, concretamente en Fuente Ovejuna el Comendador que gobierna no ejerce su poder con respeto a las leyes, por lo que el pueblo es víctima de sus abusos, y finalmente acaba acudiendo al rey para acogerse a su jurisdicción a fin de que se pueda restablecer el orden y la armonía que deben presidir la organización social.

Finalmente, para mejor comprensión de la situación jurídica en esta obra, hay que partir del hecho de que la situación descrita por Lope en su novela, ocurrió 140 años antes de que él la escribiera y que en todo momento siguió la versión dada por el cronista Francisco Rades de Andrada en su obra "Chrónica de las tres Ordenes y Caballerías de Santiago, Calatrava y Alcántara», que contempla una situación de culpabilidad del Comendador, tanto por los abusos hechos a su pueblo como por la traición a los Reyes Católicos, apoyando al partido contrario y combatiendo contra ellos en Ciudad Real.

\section{SITUACIÓN JURIDICA}

Al proceso institucionalizador iniciado tras la guerra civil (1474-1476) de sucesión iniciada tras la muerte de Enrique IV, le imprimieron los Reyes Católicos dos características: el desarrollo del aparato de gobierno que se había ido gestando durante la Baja Edad Media adaptada a los nuevos 
tiempos y los denodados esfuerzos por implantar el Derecho real. El panorama que encontraron al comienzo de su reinado, en diciembre de 1474 fue de completo desorden en la Administración de Justicia y usurpación de funciones jurisdiccionales por los grandes señores, por lo que afrontaron como más urgente necesidad la consecución del restablecimiento de la justicia, entendida en un amplio sentido, transcurriendo pocos años hasta que empezaran a cosechar éxitos en dicha misión, así como en el de seguridad de sus reinos, objetivos conseguidos mediante la consolidación del aparato institucional y la colaboración de expertos en Derecho, ya que además de legislar, los monarcas reafirmaron la prioridad del Derecho sobre otros problemas del momento, impusieron la obligación de su estudio y conocimiento para tener acceso a los oficios de justicia y en particular impulsaron a través de múltiples disposiciones su aplicación práctica y eficaz, creándose nuevos procedimientos para garantizar su cumplimiento. Pese a su esfuerzo de gobernar con justicia, existen multitud de ejemplos en los que pesando su afán absolutista, dejan de lado las disposiciones generales para dictar otras de carácter particular en beneficio de unos determinados intereses del momento.

Ya con anterioridad al inicio de su reinado, en los Capítulos de Cervera de 7 de enero de 1469 habían determinado la función que a los monarcas correspondería, entre las que se incluye...» 4.-Que observaremos y haremos obsenvar y administrar buena justicia en todos esos dichos reinos y señoríos de Castilla y León, asi en la corte como en todas otras ciudades, villas y lugares de ellos, y que con toda clemencia trataremos y oiremos a los que a nos recurrieren por justicia, según debe bueno e católico rey, y que tendremos encomendados piadosamente a los pobres e miserables personas. 5.-Idem, que por consolación de los pueblos y los hombres de ellos, no les daremos sus audiencias y los trataremos así en lo referente a la justicia, como en todas las otras cosas, con todo amor y clemencia como se debe de buen rey a sus vasallos. 6.-Idem, que observaremos y guardaremos lo establecido en las loables costumbres, fueros y privilegios de esos reinos y señorios, a todas las ciudades, villas y lugares de ellos, según suelen hacer los reyes cuando toman los regimientos de aquellos".

La reposición de la Justicia habría de comenzar por la solución de una serie de deficiencias en el orden jurídico asiduamente repetidas, tales como denegar apelaciones, alargar innecesariamente la duración de los procesos, dejar sin castigo los delitos cometidos por los señores, causar o permitir alteraciones de orden público o invadir el ámbito de otras jurisdicciones. Frente a tal caos, se consagrarían como principios del sistema jurídico: el adecuado funcionamiento de las alzadas ante el Tribunal del Rey, su Audiencia o Consejo Real, el derecho de los naturales del reino a 
acudir a la Corte y ser escuchados cuando sufrieran «mengua» de la justicia, así como la obligatoriedad de que las disposiciones reales fueran ajustadas al Derecho.

A partir de 1480 no cesarán los monarcas de crear disposiciones legales, como la Concordia de las Audiencias de 1488 o las Ordenanzas de Medina del Campo de 1489, que reorganizan la Chancillería de Valladolid y el orden judicial. En la década siguiente surgen nuevas disposiciones que afectan a diversos ámbitos de las justicias ordinarias y especiales, perfeccionándose el entramado institucional y técnico, incluso en lo relativo a los abogados y escribanos públicos. A finales de 1499 se promulgará la primera «Ordenanza para abreviar los pleitos», en 1500 los Capítulos de Corregidores, los aranceles de las justicias y escribanos y un gran número de cédulas, pragmáticas y ordenanzas que harán precisa la formación de un cuerpo legal oficial. Con gran parte de estas disposiciones se conformó el Libro de las Bulas y Pragmáticas, que con función recopiladora cubre una evidente laguna de ordenación normativa, aunque de forma incompleta en cuanto a la recopilación del orden jurídico, ante lo cual la reina en su testamento demandará la composición de un cuerpo legal más amplio para reunir aquellas disposiciones que constituyen el Derecho del reino, muchas de las cuales habian nacido de la acción concertada de aquellos monarcas. Sobre una parte de este ordenamiento se promulgaría en las Cortes de Toro la nueva legislación castellana, denominada «Las Leyes de Toro de 1505", que no fueron objeto de revisión hasta que fuera promulgada por Felipe II la denominada «Nueva Recopilación de las Leyes».

La creación del Derecho es en esta época una prerrogativa regia.

Como ya se ha apuntado, durante el reinado de los Reyes Católicos se asiste a la implantación de dos grandes principios: la estatalización del Derecho y la absorción de la facultad legislativa por los soberanos. Así la ley se convierte en obra de la razón, acto debido a la voluntad del legislador y destinado al bien público de sus súbditos, a quienes obliga, nace con carácter de estabilidad y vocación de utilidad para el mejor funcionamiento de la sociedad y finalmente, debidamente promulgado para asegurar su eficacia.

Como Derecho real se conoce a la normativa que directa o indirectamente emana del rey, y aunque formalmente es unitario, pues su origen es único, materialmente se diversifica según la intervención en su elaboración - la solemnidad de la decisión. Con arreglo a estos elementos pueden distinguirse como disposiciones reales: a) las leyes o normas generales elaboradas por las cortes o recopilación de otros textos; b) pragmáticas o normas generales elaboradas por el monarca, con la cláusula de poseer la 
misma fuerza que si dimanasen de las cortes; c) ordenanzas u ordenamientos, que son conjuntos de disposiciones para la regulación del Derecho, elaboradas con o sin intervención de las cortes; d) cédulas y decretos, que son normas generales o singulares con menor solemnidad que las leyes; e) provisiones, órdenes y resoluciones, que son normas singulares, salvo cuando tienen el título de generales, y están desprovistas de toda solemnidad; $f$ ) peticiones y capítulos de corte, o concesiones del rey en respuesta a alguna demanda de los estamentos sociales; g) autos acordados o acuerdos del Consejo Real, para aclaración de extremos dudosos de otra legislación y h) visitas o resoluciones del monarca dadas a sus enviados para inspeccionar un determinado ámbito.

El proceso de absorción de la función legislativa tuvo un desarrollo paralelo al de la concepción del poder absolutista de los monarcas, llegando a identificarse monarquía con tarea legislativa, tal y como se atribuye la reina Isabel en su testamento, al manifestar entre sus declaraciones de voluntad: «quiero e mando que sea avido, e tenido, e guardado por ley e como ley, e que tenga fuerza e vigor de ley, e no lo embargue ni pueda embargar ley, fuero, ni derecho, ni costumbre».

La progresión de la potestad legislativa de los monarcas coincide con la crisis institucional de las Cortes, al ir abandonando su participación los estamentos nobiliario y eclesiástico, controlados por la monarquía absolutista de la que son claro exponente los Reyes Católicos. El reconocimiento de esta potestad, entendida como capacidad de crear y modificar el Derecho a través de los actos de voluntad o decisiones individuales de los monarcas, es lo que se ha denominado como decisionismo jurídico castellano.

Entre las principales disposiciones normativas emanadas del poder real pueden señalarse:

- El Ordenamiento de Madrigal de 1476, que se convirtió en un cuerpo de leyes reformadoras de las instituciones públicas y del propio orden judicial, dentro del objetivo expresamente establecido por los reyes de procurar «la paz y la concordia de los pueblos».

- Ordenanzas Reales de Castilla de 1488, que constituyen el primer cuerpo recopilador de leyes elaborado durante el reinado de los Reyes Católicos, integradas por 8 libros, divididas en 115 títulos y 1.163 leyes, uniéndose al epígrafe de cada una el nombre del monarca que la promulgó, a partir de Alfonso XI, comprendiéndose en un único cuerpo legal los textos procedentes preferentemente de los Ordenamientos de Cortes. La desbordante actividad en la producción legislativa de los monarcas a través de la emisión de Pragmáticas, Cédulas, Provisiones, Ordenanzas y otras disposiciones quedarían recopiladas por orden cronológico. 
- El Libro de las Bulas y Pragmáticas de 1503.

- Las Leyes de Toro de 1505, constituirán el núcleo fundamental del Derecho privado castellano para materias tan importantes como el derecho de las personas, filiación, capacidad de la mujer y otras materias del Derecho matrimonial y del Derecho sucesorio, así como la relevante institución del mayorazgo y diversas normas de carácter civil, penal y procesal, que se convirtieron, como el Preámbulo afirma, en leyes generales del reino con preferente aplicación en los tribunales, al encomendar a los jueces que juzguen con ellas y asimismo se enseñaron en las universidades de Salamanca, Alcalá de Henares y Valladolid y posteriormente serían integradoras de la Nueva Recopilación, impresa en 1576 y la Novísima Recopilación, editada en 1805.

\section{LOS ÓRGANOS JURISDICCIONALES}

Durante el reinado de los Reyes Católicos encontramos ya una Administración de Justicia con minuciosa composición por órganos de distintos ámbitos y competencias; así en el plano superior está la justicia del monarca, $y$, descendiendo de rango hay una Administración intermedia y una Administración inferior, además de las Jurisdicciones especiales, pasando a exponer a continuación las peculiaridades de cada una de ellas.

\section{La Justicia del Rey}

Durante la Edad Media el rey se encuentra en la cúspide de la Administración de Justicia, estándole reservado dicho plano supremo con exclusividad. La justicia es considerada como oficio de reyes, como así aparece continuamente reflejado en los textos de las Cortes, así durante el reinado de los Reyes Católicos, las Cortes de Madrigal de 1476 recogieron: "conosçiendo que prinçipalmente esta administraçión e exençion de la iustiçia nos es encomendada por Dios en estos reynos y esta nos mandó amar por la boca del propheta, diziendo: amad la iustiçia los que juzgais la tierra». La exclusividad del monarca en su función judicial será regulada por una disposición de las Cortes de Toledo de 1480: «lurisdiccion suprema, civil y criminal pertenece a nos, fundada por derecho comun en todas las ciudades y villas y lugares de nuestros Reynos y señorios: $y$ por esto mandamos que ninguno sea osado de estorvar, ni impedir en los lugares de señorio la jurisdiccion suprema que tenemos, en defeto de juezes inferiores, 
para que nos la hagamos y cumplamos como convenga a nuestro servicio, y guarda de los tales lugares. Y otrosi, que no sean osados de impedir, ni estorvar las alçadas y apelaciones que los vezinos y moradores de todos y qualesquier lugares de señorio, $y$ otros qualesquier que quisiern alçarse $y$ apelar, sintiendose por agraviados delos señores dellos, o de sus Alcaldes y juezes, para ante nos en nuestras Audiencias: y no les hagan mal, ni daño alguno por esta razon; ca nos lo tomamos so nuestro seguro y amparo, ni estorvar los pleitos de las viudas, y de los huerfanos, de los pobres y personas miserables de los tales lugares, y en los casos de nuestra Corte, que por las leyes de nuestros reynos se pueden traer ante nos, ni a los agraviados que se vinieren a quexar ante nos. $Y$ otrosi mandamos a los que tuvieren assi las dichas ciudades y villas y lugares de señorio, que obedezcan y guarden nuestras cartas de emplaçamientos y mandamientos».

Corresponde al rey, como supremo administrador de la justicia, el fallo de los pleitos civiles y criminales, el conocimiento de causas por agravios inferidos a los eclesiásticos, a los concejos y en realengos y señorías. Competen asimismo al rey los llamados "casos de corte», que son: forzamiento de mujer, muerte de hombre sobre salvo o seguro, quebrantamiento de camino, quebrantamiento de iglesia, quebrantamiento de palacio, exacción indebida de conducho, pleitos sobre términos entre villas de realengo y nobles o eclesiásticos, riepto, quebrantamiento de tregua o seguros real, falsedad de moneda, sello o cartas reales, quebrantamiento de salvo, incendio de casa, traición, aleve, encartamiento de consejo o juez, ladrón conocido, pleitos de viudas, huérfanos y personas miserables, prendas de bienes y prisiones de personas, receptación de deudores y malhechores. Atributo de los monarcas fue igualmente conocer del recurso de alzada contra resoluciones dictadas en pleitos correspondientes a las tierras de su señorío.

\section{La Jurisdicción Ordinaria}

Dentro de la cual encontramos los siguientes órganos:

\section{A) El Consejo Real}

Su instauración data de 1385 , pero es bajo el reinado de los Reyes Católicos cuando experimenta su principal transformación, dejando de ser un ámbito consultivo para disputas nobiliarias, para convertirse en un órgano técnico al servicio de la corona, con destacada participación por vía de gobierno y por vía de justicia. 
Está integrado por un número variable de letrados, caballeros y un prelado, bajo la máxima autoridad del rey, quien estaría presente los días señalados 0 en aquellos asuntos que considerara conveniente. Las Ordenanzas de la Chancillería de Valladolid de 1489 detalla las vías judiciales del Consejo, conteniéndose una cláusula de reserva de jurisdicción para los casos concretos en que el rey ordenase que aquel habría de entender, así en las Ordenanzas de Medina del Campo de 1489 se disponía: «Pero que los del nuestro Consejo puedan entender e conoscer en cosas de expediente e en las residencias e mandar facer pesquisas e las de ver e determinar e en otros cualesquier casos que vieremos que cumple a nuestro servicio, en que nos les mandaremos especialmente entender e conoscer e determinar», correspondiéndole ordinariamente las cuestiones de expediente, residencias, pesquisas y aquellas otras que puntualmente le fueran remitidas. Igualmente conoce de las apelaciones en causas civiles de los Alcaldes y de los recursos de suplicación.

\section{B) La Chancillería y Audiencias}

Forma parte de la Administración intermedia y los Reyes Católicos entendieron que era «la cosa mas principal e mas excelente de la administracion y execucion de la justicia" y por ello pocos meses después de comenzar su reinado confirmaron todas las leyes, fueros y ordenamientos otorgados por los reyes, sus antecesores, a la Chancillería instalada con carácter de permanencia en Valladolid.

Está compuesta por un presidente y un numero determinado de jueces letrados y otros especializados en las cuestiones penales, que reciben el nombre de «alcaldes del crimen». Está dividida en tres Salas, dos para los asuntos de corte, suplicaciones y apelaciones de los asuntos civiles y una tercera para las suplicaciones y apelaciones de causas criminales.

Desde finales del siglo $\mathrm{xv}$, al lado de la Chancillería aparecen otros tribunales $\mathrm{u}$ órganos judiciales colegiados más modestos denominados Audiencias y que en este momento de aparición están subordinadas a la Chancillería; sin embargo, con el devenir del tiempo fueron estas últimas las que van quedando relegadas a un plano meramente honorífico, en tanto que las Audiencias toman cadia vez mas fuerza.

\section{C) Los Capítulos de Corregidores}

Son los representantes de la autoridad real en el municipio castellano. Los Corregidores remontan sus orígenes a la época de Alfonso XI, cuando 
con la finalidad de poner orden en los concejos o para inspeccionar la situación financiera se enviaban a tales representantes, denominados «jueces de salario", "veedores", "asistentes" o "enmendadores" y finalmente «corregidores». En 1480 los Reyes Católicos establecen su carácter general y acuerdan enviarlos a las ciudades y villas que no los tuvieren.

En el municipio en que reside, denominado cabeza del «Corregimiento», también denominado Partido le corresponde velar por el orden público a través, básicamente, de la jurisdicción criminal. Ejerce funciones de gobierno y de justicia, administrativas, políticas, militares y mediadoras, colocándose como nexo entre el monarca y la ciudad. El nombramiento se realiza por el rey, excluyéndose a distintas personas por razón de sexo, nacionalidad, defecto físico o indignidad, estando dicho cargo afectado por un estricto régimen de incompatibilidades, como el ejercicio de la profesión de abogado o procurador.

Sin embargo, la normativa creada al respecto no sería capaz de soportar esta institución, que decayó durante los años posteriores. La nobleza, además, trató de reafirmar su control acosando a los representantes reales, creando un clima de hostilidad contra los Corregidores, que tan solo finalizaría cuando Carlos I reafirmara la institución heredada de sus abuelos maternos, creciendo a partir de entonces en importancia y atribuciones como verdadera autoridad delegada del monarca, en un doble carácter jurisdiccional y administrativo.

\section{D) La Hermandad General}

Fue creada según el modelo ideado por el rey de Francia, con la doble finalidad de control del orden público y profesionalización del ejército, así como pretensiones de convertirla en el brazo armado de la Justicia, pues solo esta institución aparecía como recurso policial para asegurar dicho orden. Se estableció en el Ordenamiento de Madrigal de 19 de abril de 1476, declarando que la entrada en la misma era obligatoria, bajo apercibimiento de multa; su jurisdicción se ejercía también sobre despoblados (todo lugar de menos de cincuenta vecinos). Todas las ciudades, villas y lugares del reino, así de realengo como de señorío estaban obligadas a ingresar en la misma y todos sus vecinos a contribuir para el sostenimiento de las cuadrillas, iniciándose la conciencia popular de que dicha jurisdicción no hacía distinciones y que sería un organismo enfrentado a la nobleza.

Desde su creación se consideran "casos de Hermandad» y, por tanto, atribuidos a su jurisdicción, la toma de bienes muebles o semovientes, 
asalto en camino, muerte, herida o prendimiento de hombres y quema de casas, viñas o mieses. Se señalaron jueces especiales para el conocimiento de dichas causas, en las que no era necesaria la intervención de parte, no existiendo ningún lugar donde el delincuente pudiera obtener amparo. Así, cometido un delito y denunciado el hecho, los cuadrilleros iniciaban la búsqueda del mismo, haciendo repicar las campanas, extendiéndose la obligación a todas las villas y lugares, en una extensión de cinco leguas; incluso tales cuadrilleros tenían la facultad de entrar en una vivienda y registrarla. Una vez capturado el delincuente era entregado a los alcaldes. El juicio, aunque simple, precisaba de pruebas; los delincuentes no capturados eran declarados rebeldes, pero si posteriormente aparecían tenían derecho a un juicio regular con todas sus pruebas.

Los Alcaldes de Hermandad podian ejecutar por sí mismos las multas fijadas por las leyes, y también les correspondía la ejecución de la sentencia de muerte.

En diciembre de 1485 se aprobó el Cuaderno de las Leyes de la Hermandad, en la Junta General de Torrelaguna, en la que aparecen definidos dos cauces: el de la justicia ordinaria, que correspondía a los alcaldes y jueces y el de los "casos de Hermandad", que se atribuían a dos alcaldes de cada lugar, uno caballero y el otro pechero, designados cada año; así todos los delitos correspondían a la justicia ordinaria, salvo los atribuidos a la Hermandad. En dicho Cuaderno se establecieron definitivamente seis "casos de Hermandad", a saber: 1) robos, hurtos, fuerzas en personas y bienes, incluyendo violación de mujeres. La pena de muerte se reservaba para este último caso y para el resto se establecían condenas pecuniarias. 2) asalto en caminos, muerte o herida a traición o con alevosía en yermo o despoblado y asechanza sin consumar el delito para cometer robo o asesinato. Las penas eran de muerte. 3) secuestro, cárcel privada o prendimiento efectuado por personas que no fuesen jueces o no contasen con mandamiento de juez. Se consideraba agravante si el hecho se cometía en la persona de algún recaudador o arrendador de rentas reales. 4) incendio provocado cuando afectaba a casas, viñas, mieses o colmenas, en despoblado o yermo 5) muerte, herida o detención de cualquiera de los oficiales de Hermandad en el ejercicio de sus funciones. La Hermandad General ya no sería renovada en 1498.

\section{Las Jurisdicciones especiales}

Las tendencias centralizadoras y estatales de los Reyes Católicos, puestas ya de manifiesto a partir de las Cortes de Madrigal de 1476 y, 
sobre todo, de Toledo de 1480 , en las que la justicia aparece concebida como una atribución del estado, y cuyo ejercicio corresponde a las jurisdicciones ordinarias establecidas por un orden jerárquico, supuso también el reconocimiento de otras jurisdicciones especiales, reguladas igualmente por la legislación general del reino y vinculadas con la jurisdicción ordinaria a través del sistema de apelación. Es de gran interés observar el ejercicio de la justicia en estas jurisdicciones especiales, que corresponden a los estatutos privilegiados de una sociedad con pervivencias estamentales.

\section{A) La jurisdicción señorial}

Los señoríos mantuvieron su excepcionalidad jurisdiccional durante todo el reinado de los Reyes Católicos, correspondiéndoles a los señores el pleno ejercicio de la justicia en el territorio y habitantes de su señorío, tanto en causas civiles como militares, y tanto en primera instancia como en grado de apelación, salvo el derecho superior del monarca de nombrar alcaldes reales cuando lo considerase conveniente por razones de oportunidad.

\section{B) La jurisdicción de Hidalguía}

Los hidalgos eran en esta época una clase numerosa, cuyos privilegios fueron confirmados en las Cortes de Toledo de 1480, como contraprestación al apoyo militar y político que habían prestado a la reina Isabel en la guerra de sucesión, y a los que se reconocía una jurisdicción especial, que correspondía ejercer al Alcalde de los Hijosdalgo, debiendo ser éstos personas de leyes quedando por tanto excluidas las demás justicias del reino.

\section{C) La jurisdicción de las Ordenes Militares}

Éstas aparecen en la sociedad feudal con la finalidad de defensa de la cristiandad respecto de otras religiones o pueblos extranjeros, perfilándose como el único ejército con carácter de permanencia. Las tres principales Ordenes de Caballería españolas se fundan en el siglo XII y son: Calatrava (1164), Santiago (1175) y Alcántara (1177). Sus miembros, a los que se exigen votos de obediencia y castidad (no de celibato) son de dos clases: clérigos, dedicados a la vida contemplativa y al servicio espiritual y frailes caballeros, consagrados a la vida militar. Cada Orden tiene una rígida estructura jerárquica interna, en cuya cúspide se encuentra el 
Maestre, con las máximas prerrogativas de gobierno y económicas, al serle atribuida la percepción de distintos impuestos, propiedades y el privilegio del hospedaje; el siguiente rango de importancia en la Orden es el Comendador, que igualmente goza de grandes privilegios, al ser el lugarteniente del Maestre. Todos sus miembros son titulares de privilegios aristocráticos y de inmunidad eclesiástica.

Los Reyes Católicos habían comprobado ya antes de su reinado la prepotencia de los Maestres, los abusos cometidos al amparo de dichas inmunidades, y sobre todo sus intentos de modificar por la fuerza las condiciones de los habitantes de los nuevos territorios anexionados y evitar su deseo de incorporarse a la jurisdicción real, por lo que finalmente fueron anexionados a la Corona.

\section{D) La jurisdicción Eclesiástica y el Patronato Real}

Su ejercicio se impartía no solo en esferas de su competencia por razón de la materia (cuestiones que afectaban a la religión católica), sino también para las causas civiles o criminales con ellas relacionadas, como el matrimonio, la herejía, la hechicería, el sacrilegio y la usura.

Además dicha jurisdicción, se convirtió en competente por razón de la persona en virtud del «privilegium fori»: si el demandado o el inculpado eran eclesiásticos, familiares o dependientes de éstos, correspondía el conocimiento de la causa a la misma.

\section{LOS PROFESIONALES DE LA JUSTICIA}

Durante el reinado de los Reyes Católicos se mantuvieron tres estadios en la Justicia: central, territorial y local.

En el nivel central, en el que el rey ejerce personalmente la Justicia, lo hace auxiliándose de su Corte, en la que como figuras expertas en Derecho aparecen los «Alcaldes de Corte» o «Jueces de Corte», que desempeñan funciones judiciales en nombre del rey, tanto en materia criminal, en aquellos casos que por su relevancia social estén reservados a la jurisdicción del monarca, como en el ámbito civil, si bien solo conocerán por vía de recurso contra resoluciones de los jueces inferiores.

En el nivel territorial aparecen los órganos colegiados, como derivación de la Chancillería con dos ámbitos de actuación distinta: por un lado documentar la actuación judicial del rey a cargo de una sección compuesta por 
juristas y eclesiásticos, cuyos miembros reciben el nombre de "Oidores", pues su misión es escuchar las suplicas de los particulares y designar a los jueces que han de resolverlas. Otros profesionales de esta organización territorial son los "Procuradores", que surgen en la Corona de Aragón, con jurisdicción propia y ordinaria reconocida por la ley, si bien además de administrar su Justicia propia puede intervenir presidiendo la audiencia del rey como su delegado territorial. Además de la Chancillería ubicada en Valladolid, existe la jurisdicción territorial de Vizcaya y progresivamente se irá desarrollando un conjunto de Audiencias Territoriales, a las que se unirán los Jueces de Apelación en Canarias, los Alcaldes Mayores en Oviedo y los Jueces de Grados en Sevilla.

El órgano judicial local castellano lo constituye el «Alcalde», que nace con el concejo castellano que es quien lo elige. En las villas el número de Alcaldes suele ser de uno o dos, aunque en las ciudades puede haber hasta dieciocho, en cuyo caso actúan colegiadamente. Aunque normalmente solo les corresponde el conocimiento en primera instancia de los asuntos, extraordinariamente puede el propio concejo nombrar «Alcaldes de Alzada» para revisión de los asuntos ya juzgados. Con la instauración de los Corregidores a finales del siglo XV con carácter permanente como agentes del rey, a los Alcaldes solo les corresponde juzgar asuntos de menor importancia.

Numerosas disposiciones de los Reyes Católicos regulan el régimen de los oficiales de la Justicia y se les exige conocimientos y experiencia jurídica «sean buscados y nombrados por oidores y aún por alcaldes hombres de conciencia y buenas letras, que lo uno sin lo otro non bastaría". Además del juramento, ya recogido en las Partidas para todos los oficiales del rey y el cumplimiento de las funciones especificadas en su carta de nombramiento, se les requiere no exigir otro salario que el regulado ni dádivas, y les está prohibida la préctica del comercio, el ejercicio de la Abogacía ni acumular más de un oficio.

Bajo el reinado de estos monarcas maduró la judicatura como oficio, con carácter de permanencia en cuanto al cumplimiento veraz y personal y la estimación de los méritos profesionales.

La profesión de la Abogacía se consolidó como consecuencia del auge en los estudios de Derecho en las dos grandes universidades del reino y el propio desarrollo institucional de la justicia, el desarrollo de las ciudades y villas y la transformación económica y social que hace necesaria la contratación de letrados públicos con cargo a las arcas municipales. Se configuró un ordenamiento completo de las profesiones de la Abogacía y la Procuraduría, otorgado en 1495, en el que se contienen leyes sobre la 
matriculación de Abogados, el juramento, el deber de capacitación y el alcance de las obligaciones de defensa, las responsabilidades por daños derivados de su impericia o negligencia y la obligatoriedad en la continuación de la defensa, entre otros.

En cuanto a la política notarial de los Reyes Católicos, en las Ordenanzas Reales de Castilla se dedica el Libro II a los escribanos de las ciudades y se dispone que éstos cuenten con un libro de protocolo encuadernado, en el que se inscriban las escrituras, de manera que sin la redacción del asiento en el protocolo, no puede el escribano otorgar escritura signada. Las notas deberán escribirse «en buena letra cortesana y no procesada", no dejando grandes márgenes; se establecen como solemnidades la fecha, el lugar y la firma del otorgante y se consagra la "fe de conocimiento". También se regula el acto solemne del otorgamiento, su unidad de celebración, los testigos y la obligación de los escribanos de conservar en su protocolo los documentos originales, de los que se extraerían las segundas copias y testimonios.

\section{EL ORDENAMIENTO PROCESAL}

Simultáneamente a la transformación del Derecho durante el reinado de los Reyes Católicos, se iría produciendo mediante Pragmáticas Reales, Ordenanzas y Ordenamientos, una amplia regulación de todas las ramas del Derecho, tanto que muchas de las instituciones vigentes en los posteriores reinados de los Austrias, en materias de Derecho privado, penal y procesal provienen de esta normativa.

Las Leyes de Toro constituyen un cuerpo de 83 disposiciones cuya finalidad es consagrar el orden de prelación de fuentes jurídicas aplicables por los tribunales del reino y resolver las contradicciones y vacíos legales existentes entre los diversos textos vigentes: el Fuerzo Real, las Partidas, Ios Fueros Locales y el Ordenamiento Real u Ordenamiento de Montalvo, en la medida en que esta recopilación contenía el derecho vigente castellano; en su contenido se abordan cuestiones de gran significación, relativas al Derecho de familia y sucesiones, el Derecho de propiedad y otras materias del Derecho privado, así como otras del Derecho procesal y penal. Es en general un derecho coherente y propio que no asume especialidades forales procedentes de fueros concretos, salvo en concretas ocasiones. De la virtualidad de este ordenamiento y su bondad técnico-jurídica se ve avalada por el hecho de que muchas de sus disposiciones han llegado hasta la Codificación y no pocas se contienen aún en la ley de 1881. 
En las Cortes de Madrigal de 1476 se estableció: «Don Fernando e Doña Isabel.... facemos vos saber que nos somos informados que en las causas, pleitos e negocios que están pendientes asi en el nuestro Consejo e en las nuestras Audiencias, como ante vos los dichos nuestros Alcaldes de la dicha nuestra Casa e Corte e Chancillería e Corregidores e asistentes $e$ alcaldes e otros nuestros jueces, así delegados como ordinarios de esas ciudades e villas e lugares, se dilata mucho la prosecucion e determinacion de los dichos pleitos e causas e negocios, asi por las malicias e cabilaciones de los pleiteantes e de sus abogados e procuradores, como por razon de las dichas delaciones que en cada parte de los pleitos e negodios se dan por las leyes de las Partidas e de los Fueros e Ordenamientos e Derecho Comun e estilo de nuestro Consejo e de las nuestras Audiencias e otras audiencias inferiores, asi en la ordenacion como en la disension de ellos. E otrosi por la diversidad e ambigüedad de opiniones de doctores que los jueces e sus asesores fallan para la determinacion de las causas.... de lo cual todo nuestros subditos e naturales se fallan muy agraviados e se les recrescen grandes costas e fatigas".

De lo anterior se infiere la preocupación de los monarcas por la situación de la administración de justicia, la lentitud de los pleitos, la falta de unanimidad en la aplicación de las leyes y los perjuicios que de todo ello se derivan para los súbditos. También los Procuradores venían reclamando entre sus peticiones a las Cortes la necesidad de mejorar el funcionamiento de la justicia, acabar con las frecuentes dilaciones por razones de procedimiento, de los medios utilizados, de los pleiteantes o del propio sistema procedimental vigente que hacían de la Justicia un mecanismo costoso y lento.

El primer ordenamiento otorgado por los Reyes Católicos para abreviar los pleitos será la Pragmática de 1499, concediendo carácter supletorio, en caso de duda o falta de ley, a las opiniones de Bartolo y Baldo en materia civil y de Juan Andrés y del Abad Fanormitano en materia canónica, pero dada la escasa eficacia de estas Ordenanzas, fueron derogadas en las Cortes de Toro, sucediendo otras posteriores: Madrid (1499), Madrid (1502) y Alcalá de Henares (1503), dirigidas como establecen sus Preámbulos a abreviar los pleitos: "DonFernando e Doña Isabel.... Bien sabedes como porque fuimos informados que en prosecucion e determinacion de los pleitos e causas que venian asi al nuestro Consejo como a las nuestras Audiencias, como a las que pendian ante los otros jueces de los nuestros reinos, se daba mucha dilacion.... que la orden de juicio e procesos e autos judiciales se fagan ordenadamente, que las partes pongan muy declarado asi lo que piden como lo que defienden y que las probanzas no se fagan confusas e superfluas e todo se faga con la mayor brevedad que se pudiere». 
Desde el punto de vista de la dirección del procedimiento, en éste pueden dominar los principios acusatorio (predomina en el proceso civil) o inquisitivo (impera en el penal), según corresponda al juez o a los propios litigantes el impulso procesal. En estos periodos de inseguridad jurídica y social se instauran en el ámbito penal procedimientos de represión instantánea de los delitos, entre los que se encuentran: el procedimiento in fraganti, el procedimiento de apellido, el de escodriñamiento, el de aprehensión, el de acorralamiento, el de elección de enemigo y el de desafío. Entre los procedimientos de garantía personal se encuentran: el de «salva fe» y el de «manifestación», y entre los de garantía real: los interdictos, el procedimiento de aseguramiento de la propiedad, el de jactancia, el de "otorrricia o intertiatio" y el de tenuta.

También existe el recurso al arbitraje como resolución extrajudicial de la contienda, basada en la voluntad de las partes, que sustituye al proceso, distinguiéndose el resuelto por "árbitros», que juzgan conforme a Derecho, y el realizado por "amigables componedores", que fallan según su conciencia, siendo su función, en ambos casos, voluntaria hasta que se acepta la designación, siendo nulo el laudo contra legem

En cuanto al desarrollo del procedimiento judicial y dado que en este breve trabajo no pueden exponerse de forma prolija todas las características del mismo, sólo se hará mención a aquellos elementos mas trascendentes, bien por su innovación, bien por la generalidad en su aplicación en los distintos reinos de los que fueron soberanos los Reyes Católicos.

- En los procesos civiles, salvo cuando se trata de desvalidos, las partes suelen ser particulares, en tanto que en los penales la acusación corresponde a un órgano público, como son los Procuradores Fiscales desde el siglo XIV. La condición de parte presupone la capacidad jurídica, procesal y de obrar, con algunas excepciones, como la que recae sobre la mujer casada, salvo licencia marital o judicial; también se contemplan incapacidades relativas, en atención a determinadas personas, como descendientes contra ascendientes, libertos contra patronos, hermanos contra hermanos 0 los cónyuges entre sí. Además de exigirse capacidad se exige como parte litigante la legitimación, esto es, tener interés directo en el pleito.

- En cuanto a la determinación del órgano judicial, en este tipo de sociedad estamental se lleva implícito un conflicto jurisdiccional, ya que cada uno de los estamentos aspirar a ejercer la jurisdicción sobre los miembros de su grupo, siendo las jurisdicciones más importantes en conflicto con la civil la militar y la eclesiástica. También existe la posibilidad de recusación del «juez sospechoso de ser odioso a una parte o favorable a la otra». 
- Aparecen con carácter de generalidad los fenómenos de la representación y defensa procesales. En virtud de la primera, la actuación de las partes litigantes se efectúa no por los propios interesados, sino por otra persona denominada «Procurador», quien actúa como mandatario de su representado en virtud de un encargo plasmado de un documento denominado "poder», el cual tiene que ser considerado bastante por el Letrado. Una vez aceptado el poder, el Procurador está obligado a seguir hasta el fin del proceso y responde de su actuación. Aunque la representación se permite en la generalidad de los casos, en el derecho local castellano se prohíbe en los procesos criminales de mayor importancia.

- En cuanto a la defensa, como actuación técnica, es ejercida por Abogados, sometidos a una serie de incapacidades, siendo la tendencia general el que todos los pleiteantes estén provistos del mismo, encontrándose en distintos ordenamientos disposiciones para que se dote de defensores gratuitos (abogados de pobres) a quienes no pudieren pagar sus honorarios. Dichos Abogados igualmente están sometidos a una serie de prohibiciones, entre las que cabe destacar: la de descubrir el secreto confiado por su cliente, invertir parte de lo recibido en el litigio en pago de sus honorarios y la ayuda a la parte contraria.

- Los procesos civiles se inician a instancia de parte y el acto incoador puede ser oral o escrito, si bien en las causas de cuantía inferior está prevista la forma verbal. Cuando se debiere hacer en forma escrita se hará a través de la demanda, que habrá de ser razonada y atenerse a los modelos establecidos. En cuanto a la incoación de los procedimientos penales, el juez puede proceder de oficio, sin necesidad de acusación de los particulares, si bien estos tienen la posibilidad de formular denuncia, sin que por ello adquieran la condición de parte.

- Tras la incoación del procedimiento se pretende la presencia del demandado del mismo, a través de la denominada «llamada a Derecho» o citación, que normalmente realiza el órgano judicial a través de los andadores o alguaciles. Tal citación podrá hacerse: por escrito mediante documento; de palabra en casa del demandado o de palabra públicamente. En el caso de que en la citación se otorgase un plazo para comparecer, este acto se denomina «emplazamiento».

- También se regulan las figuras de la rebeldía: cuando el demandado no comparece y se permite continuar el trámite sin su presencia, aunque antes se ensayen medios coactivos como la prenda, y el allanamiento: forma más habitual de finalización de los procesos judiciales, con la conformidad del demandado a las pretensiones del demandante. El allanamiento es una institución propia del proceso civil, pero se le da 
igual tratamiento a la confesión espontanea del reo en el proceso penal aragonés.

- Se establecen formas de garantía en el procedimiento, que son: a) el juramento de la parte demandante de que lo que demanda es verdadero, b) la fianza personal, que corresponde otorgar al demandado, c) la detención, que garantiza la presencia del reo en el proceso criminal, y también puede ser un medio subsidiario por no haberse prestado fianza y d) el embargo, como garantía patrimonial subsidiaria de la garantía personal, por incomparecencia o ausencia maliciosa y por rebeldía tras tres emplazamientos. Desde el Ordenamiento de Alcalá se distingue entre el embargo antes citado, de naturaleza preventiva, y el embargo realizado para ejecución de la sentencia.

- Se establecen una serie de fases en el procedimiento que son: la iniciación, la perfección, la prueba y la resolución, correspondiendo el paso de una fase a otra al impulso procesal de las propias partes en los procedimientos civiles y al propio órgano jurisdiccional en los penales.

- La prueba se diversifica en diversos medios: a) medios subjetivos, como la confesión, el juramento, el testimonio, la notoriedad, la presunción y el tormento; b) medios objetivos, como los documentos, libros de comerciantes, dictámenes de peritos e inspección ocular y c) medios ordálicos, en los que se encomienda a una actitud de la divinidad que el hombre interpreta a través de signos materiales. La práctica de la prueba se realiza dentro de los plazos establecidos. La carga de la prueba corresponde a quien alega su derecho y la apreciación de la misma puede ser realizada: a) de forma automática, atendiendo exclusivamente a su resultado, b) de forma legal, interpretándola conforme a las reglas legales y c) de forma libre, con arreglo a la convicción obtenida por el juez.

- El proceso finaliza mediante la sentencia, en la cual se resuelven las cuestiones debatidas en el pleito. El juez está obligado a dictar sentencia, no pudiendo rehusar el fallo amparándose en silencio, oscuridad o insuficiencia de la ley. En la redacción de las sentencias se han de cumplir unos requisitos de forma: ha de ser motivada y en ella se expondrán separadamente los resultandos (hechos), los vistos (normas aplicadas), los considerandos (razones por la que se han aplicado dichas normas y el fallo, que es la parte dispositiva.

- Se establece un sistema de recursos contra las resoluciones judiciales, de naturaleza ordinaria, cuya resolución se encomienda al juez ad quem, y son el de alzada o apelación y aquellos cuya resolución corresponde a una autoridad suprema, que son el de súplica y casación 
- La ejecución puede ser voluntaria, cuando la parte vencida da cumplimiento voluntario a la sentencia y debe realizarla en el plazo señalado por el juez en cada caso, y forzosa, que corre a cargo de la autoridad judicial que ha dictado la sentencia y puede ser: a través de las garantías en su momento prestadas, en los bienes del vencido (embargándolos y subastándolos) o en la persona del vencido, con su detención.

\section{EL DERECHO PROCESAL EN «FUENTE OVEJUNA»}

\section{La situación social}

La situación social en esta villa es de opresión y atropello del señor feudal —el Comendador Fernán Gómez de Guzman- hacia sus vasallos, pues además de usar y abusar de los derechos que las leyes le concedían, se atribuía otros, como el derecho de pernada o el de hospedaje y manutención de sus soldados, el trato lujurioso a las mujeres de la villa, tanto casadas como solteras.

Todo ello en el ámbito de una sociedad feudal tardía, en la que Fuente Ovejuna está sometida no a la monarquía de los Reyes Católicos, sino a la Orden de Calatrava. El Comendador que la gobierna no ejerce su poder con respeto a las leyes y por consiguiente traiciona los principios feudales de los que dimana su autoridad.

Centrándonos en la Orden de Calatrava, a la que pertenecían tanto el Maestre como el Comendador que aparecen en la obra, hay que remontarse al año 1445, en el que fue elegido Maestre D. Pedro Girón, quien mantuvo permanentemente una política de intrigas, favores y traiciones; devaneos en los que siempre sacaba proveho, pués por encima de todo pesaba su excesiva ambición. Así Pérez Guzman en su obra "Generaciones y Semblanzas" cita: "fue codicioso en un grande estremo de vasallos y tesoros, tanto que ansí como idrópigos nunca pierden la sed, ansí el nunca perdía la gran gana de aver, nunca recibiendo hartiva su insaciable codicia ça en el día que el rey le dava o, mejor diría, le tomaría una lanza del rey si vacase, ansí que deseando lo mucho no desdeñaba lo poco».

Tanto fue su ánimo de poder que llegó a conseguir el compromiso de matrimonio con la entonces princesa Isabel de Castilla (previamente había obtenido la dispensa papal de castidad y había renunciado a todas sus pertenencias a favor de su hijo), matrimonio que no llegó a celebrarse al sobrevenirle la muerte repentina. 
En el Maestrazgo de Calatrava le sucedió su hijo Rodrigo Téllez Girón en 1474, cuando contaba con 16 años. Entre las posesiones del mismo hay que citar 350 villas, lugares, aldeas, fortalezas, caseríos y heredades, con una población de 200.000 personas. Entre estas poblaciones no se encontraba la de Fuente Ovejuna, que le había sido dada en heredad a su padre D. Pedro Girón por el rey Enrique IV, otorgando a la misma el privilegio de independencia, eximiéndole del dominio que hasta entonces había tenido Córdoba y concediéndola por sí jurisdicción civil y criminal y facultad de elegir Concejo y Ayuntamiento. Posteriormente, el propio Pedro Girón, a su conveniencia hizo un trueque con la Orden de Calatrava para que le diesen las villas de Osuna y Cazalla por los lugares de Fuente Ovejuna y Bélmez, renunciando expresamente a éstas, por lo que hecha la permuta con la Orden, ésta se quedó con las últimas.

\section{La actuación de los vecinos}

La crónica de lo sucedido, según F. Rades de Andrada (Chrónica de las Tres Ordenes), es la siguiente: «Don Fernan Gomez de Guzman, Comendador Mayor de Calatrava, que residía en Fuente Obejuna, villa de su Encomienda, hizo tantos y tan grandes agravios a los vezinos de aquel pueblo, que no pudiendo ya sufrirlos ni disimularlos, determinaron todos de un consentimiento y voluntad, alzarse contra él y matarle. Con esta determinación y furor de pueblo ayrado, con voz de Fuente Obejuna, se juntaron una noche del mes de abril del año mil e quatrocientos e setenta seis, los alcaldes, regidores, justicias e regimiento con los otros vezinos, y con la mano armada entraron por fuerza en las casas de la Encomienda Mayor, donde el dicho Comendador estava. Todos apellidaron Fuente Obejuna y decian «vivan los Reyes Don Fernando y Doña Isabel y mueran los traidores y malos christianos". El Comendador Mayor y los suyos, quando vieron esto y oyeron el apellido que llevaban, pusiéronse en una pieza, la mas fuerte de la casa, con sus armas, y alli se defendieron dos horas, sin que se les pudiera entrar. En este tiempo, el Comendador Mayor a grandes vozes pidió muchas vezes que le dixessen qué razón o causa tenian para hacer aquel escándoloso movimiento para que él diesse su descargo y desagraviasse a los que dezían estar agraviados dél. Nunca quisieron admitir sus razones, antes con grande ímpetu, apellidando «Fuente-Obejuna», combatieron la pieza, $y$ entrados en ella mataron catorce hombres que con el Comenddor estavan, porque procuravan defender a su señor. Desta manera, con un furor maldito y ravioso, llegaron al Comendador, y pusieron las manos en él y le dieron tantas heridas que le hizieron caer en tierra sin sentido. Antes que diesse el ánima a 
Dios, tomaron su cuerpo con grande y regocijado alarido, diziendo: "vivan los Reyes y mueran los traydores" y le echaron por una venta a la calle; $y$ otros que alli estavan con lanzas y espadas, pusieron las puntas arriba para recoger en ellas el cuerpo que aun tenía ánima. Después de caydo en tierra, le arrancaron las barbas y cabellos con grande crueldad; y otros con los pomos de las espadas le equebraron los dientes. A todo esto añadieron palabras feas y descorteses y grandes injurias contra el Comendador Mayor, y contra su padre y madre. Estando en esto, antes que acabasse de espirar, acudieron las mugeres de la villa, con panderos y sonages a regocijar la muerte de su señor; y avian hecho para esto una vandera, y nombrado Capitana y Alférez. También los muchachos, a imitación de sus madres, hizieron su capitanía, y puestos en la orden que su edad permitila, fueron a solemnizar la dicha muerte; tanta era la enemistad que todos tenían contra el Comendador Mayor. Estando juntos hombres, mugeres y niños, llevaron el cuerpo con grande regocijo a la plaza; $y$ alli todos, hombres y mugeres, le hizieron pedazos, arrastrándole y haziendo en él grandes crueldades y escarnios; y no quisieron darle a sus criados para enterrarle. Demás desto dieron sacomano a su casa, y le robaron toda su hazienda".

En la propia obra de Lope de Vega, Flores (criado del Comendador) acude ante el rey D. Fernando a darle cuenta de los hechos:

«Rey supremo,

mis heridas no consiente

dilatar el triste caso,

por ser mi vida tan breve.

De Fuente Ovejuna vengo,

donde, con pecho inclemente,

los vecinos de la villa

a su señor dieron muerte.

Muerto Fernán Gómez queda

por sus súbditos aleves;

que vasallos indignados

con leve causa se atreven.

Con título de tirano

que le acumula la plebe,

a la fuerza de esta voz

el hecho fiero acometen;

y quebrantando su casa,

no atendiendo a que se ofrece

por la fe de caballero

a que pagará a quien debe, 
no sólo no le escucharon, pero con furia impaciente rompen el cruzado pecho con mil heridas crueles $y$ por las altas ventanas le hacen que al suelo vuele, adonde en picas y espadas le recogen las mujeres. Llévanle a una casa muerto, $y$, a porfía, quien más puede mesa su barba y cabello y apriesa su rostro hieren. En efeto fue la furia tan grande que en ellos crece, que las mayores tajadas las orejas a ser vienen. Sus armas borran con picas $y$ a voces dicen que quieren tus reales armas fijar, porque aquellas les ofenden.

Saqueáronle la casa, cual si de enemigos fuese, y gozosos entre todos han repartido sus bienes. Lo dicho he visto escondido, porque mi infelice suerte en tal trance no permite que mi vida se perdiese; y así estuve todo el día hasia que la noche viene, y salir pude escondido para que cuenta te diese. Haz, señor, pues eres justo, que la justa pena lleven de tan riguroso caso los bárbaros delincuentes: mira que su sangre a voces pide que tu rigor prueben".

La valoración de estos hechos ha sido objeto de múltiples estudios y versiones, desde el cronista de Enrique IV, que entiende la revuelta como 
el resultado de una conspiración manejada e impulsada por dos grandes, en los que los habitantes de Fuente Ovejuna serían meros ejecutores de las órdenes dadas, hasta los que mantenían que fue una sublevación de carácter político, bien porque los habitantes de Fuente Ovejuna, hartos de los desmanes y abusos del Comendador, se pronunciaron a favor de los Reyes Católicos, bien porque el motín fue inspirado por la ciudad de Córdoba para recuperar su señorío sobre la villa, basándose en documentos reales en los que se autorizaba y se daba vía legal a las insurrecciones de las villas y ciudades contra los señores que las ocupaban y conservaban sin respetar la voluntad de los lugareños.

\section{El proceso}

De los hechos ocurridos y anteriormente expuestos dimanan dos procedimientos: uno penal encaminado a determinar el autor o autores de la muerte del Comendador y otro civil, mediante el que se perseguía por un lado, la restitución de los bienes usurpados por el Comendador, y por otro determinar la jurisdicción de la villa de Fuente Ovejuna.

\section{A) El proceso penal}

Es muy breve y se inicia con el envío por parte de los Reyes Católicos de una Comisión dada al Juez Pesquisidor (Don Juan de Luvian) para practicar cuantas diligencias fueran necesarias en averiguación de los hechos, la instrucción hecha por éste, su comparecencia ante los reyes dando cuenta del resultado negativo de sus pesquisas y el fallo absolutorio inmediato de éstos.

Así en la obra de Lope de Vega, el rey Don Fernando, a requerimiento de Flores (criado del Comendador ya muerto) tras relatarle los hechos ocurridos en la villa, da la siguiente respuesta:

\footnotetext{
«Estar puedes confiado que sin castigo no queden.

El triste suceso ha sido tal, que admirado me tiene, y que vaya luego un juez que lo averigüe conviene, y castigue a los culpados para ejemplo de las gentes.
} 


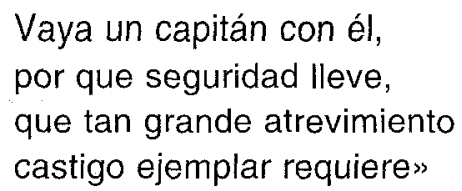

Así los Reyes Católicos el 10 de mayo de 1476 (los hechos habían ocurrido el 23 de abril), comisionan al Juez Pesquisidor D. Juan de Luvian, a petición de los criados del Comendador Mayor de Calatrava, para que investigue sobre su muerte y contra los vecinos de Fuente Ovejuna que le mataron y robaron sus bienes, siendo dicha Comisión del siguiente tenor literal (Archivo General de Simancas, Registro General del Sello, fol. 375):

"Don Fernando y Doña Isabel, etcétera, a vos Juan de Luvián, nuestro criado, salud e gracia. Sepades que Diego de Pires e Martín, criados del Comendador Mayor de Calatrava, ya defunto, nos fizieron relación que ya sabíamos, como de pocos dias a esta parte algunos vezinos e moradores de Fuente-oveguna mataron al dicho Comenddor Mayor e le tomaron e ocuparon todos sus bienes, oro e piata, joyas e caballos, azémilas e armas, e otras cosas, e asi mismode sus criados e escuderon que con el estavan e que los dichos bienes $s$ los tomaron e tienen ocupados e entrados e otras algunas cosas contra todo derecho; e dizen que el dicho Comendador Mayor fue enterrado en un corral de un monasterio de unos frailes por merced que nos suplicavan que mandásemos se pusiesen recaudo en los dichos bienes que fueron en fincaron del dicho Comendador Mayor, e mandásemos restituir e entregar a los dichos sus criados todos los bienes que asi le fueron tomados, e que a costa de los dichos sus bienes, el dicho Comendador Mayor fuese enterrado honrosamente en el lugar donde él tenía nombrado para ser enterrado; e que sobre todo proveyésemos como nuestra merced fuese e nos tuvimos por bien e confiado de vos que guardáredes vuestro servicio e el derecho de las partes, mandamos dar a esta carta por la cual os mandamos que luego vista, vayades a la dicha villa de Fuente-oveguna, e a otros lugares de su comarca, donde viéredes que cumple, e sepais la verdad por cuantas partes e maneras, mejor e más cumplidamente lo pudiéredes saber, en cuyo poder están los dichos bienes o otras cosas quales quier asi del dicho Comendador Mayor, que así fueron tomadas. Todos los bienes e otras cosas que halláredes del dicho Comenddor Mayor, los saquedes de poder de quien los halláredes. Ca por esta carta mandamos a las personas que los tienen que os los den e entreguen en el término, so las penas que vos mandáredes, e los pongades en poder de buenas personas, llanas e abonadas, por inventario e ante escrivano público, para que los tengan en la dicha secuestración e non recudan con ello a persona alguna sin nuestro mandato. De todos los bienes que halláredes de los criados e escuderos del dicho Comendador Mayor que por causa de los susodichos les fueron tomados injusta e non debidamente, los fagais luego restituir e entregar libremente, sin contra alguna; e otrosí os mandamos que luego hagais sacar al dicho Comendador Mayor de donde dicen que asi está enterrado deshonrradamente, e de los dichos sus bienes le hagais enterrar e se le hagan sus honras e enterramiento honrrosamente, según su estado, para 
to qual todo que dicho es...; e las quales nos por la presente las ponemos mandamos saquedes e llevedes de vuestro salario e para vuestro mantenimiento de 60 dias que os damos para lo susodicho, doscientos maravedís cada dia e los ayades e os sean pagados de los bienes del Comendador Mayor, de los quales os podais entregar por vuestra propia autoridad. E mandamos al Concejo, Alcaldes e Alguacil, Regidores, Oficiales e omes buenos de la villa de Fuenteovejuna e a otos cualesquier Concejo, justicias, de su comarca, e a cada uno de ellos, que os den e hagan dar todo el favor e ayuda que les pidiéredes e menester hubiéredes e que os non pongan ni concientan poner en ello o en part de ello embargo ni contrario alguno. E non hagades ni hagan ende al por alguna manera, so pena de la nuestra merced e de privación de los oficios, confiscación de los bienes de los que contrario hizieen para la nuestra cámara e fizco. Valladolid a 10 dias de mayo, anno de 1476».

En la Comisión dada se encarga al Juez Pesquisidor la averiguación de los hechos tanto de índole civil como penal. En cuanto a los primeros, me referiré en el correspondiente apartado, y en cuanto a los segundos hay que destacar los siguientes datos:

- Los comisionantes fijan un plazo para la práctica de lo interesado de sesenta días.

- Que autorizan al Juez implícitamente para el empleo de cualquier método que ayude en su investigación ( $e$ sepais la verdad por cuantas partes e maneras, mejor e mas cumplidamente la pudiéredes saber»).

- El devengo de costas judiciales, dimanadas de las pesquisas encargadas, que han de ser satisfechas con cargo a los bienes del Comendador.

- El mandato de auxilio judicial en la investigación

- El castigo para quienes no prestaren la colaboración requerida y para el propio Juez en cumplimiento de lo ordenado ( $e$ non hagades ni hagan ende al por alguna manera, so pone a de la nuestra merced e de privación de los oficios, confiscación de los tienes").

Sin embargo, bajo la solidaridad colectiva, la respuesta del pueblo fue inalterable e hizo imposible el procedimiento penal al uso: determinar la culpabilidad y establecer la escala de responsabilidad ante la multiplicidad de autores, suponiendo que la pena habría de imponerse a todos o absolverlos

Así Lope relata en su obra el resultado de las pesquisas y su comunicación al rey por parte del Juez:

«A Fuente Ovejuna fui

de la suerte que has mandado, 


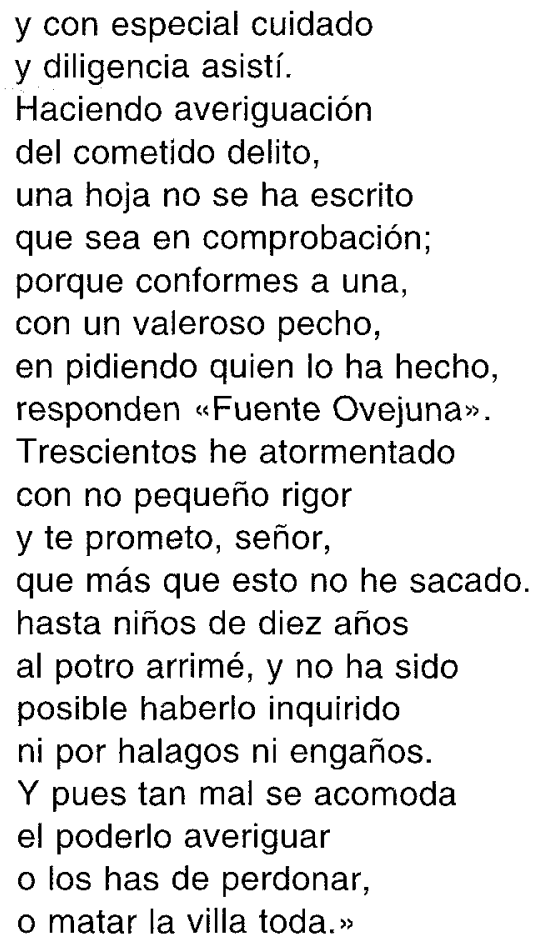

Según la crónica de Rades de Andrada, estos hechos ocurrieron en la siguiente forma: «Fue de la Corte un Juez Pesquisidor a Fuente-obejuna con comisión de los Reyes Chatólicos, para averiguar la verdad deste hecho y castigar a los culpados; y aunque dio tormento a muchos de los que se avian hallado en la muerte del Comendador Mayor, nunca quiso confessar quales fueron los capitanes o primeros movedores de aquel delicto, ni dixeron los nombres de los que en él se avían hallado. Preguntávales el Juez: "¿quién mató al Comendador Mayor?". Respondían ellos "Fuente-obejuna». Preguntávales: “¿quién es Fuente-obejuna?». Respondían: «todos los vezinos desta villa". Finalmente todas sus respuestas fueron a este tono, porque estavan conjurados que aunque los matassen a tormentos no avían de responder otra cosa. Y lo que más de admirar que el Juez hizo dar tormento a muchas mugeres y mancebos de poca edad, y tuvieron la misma constancia y ánimo que los varones muy fuertes. Con esto se bolvió el Pesquisitor a dar parte a los Reyes Chatólicos, para ver que mandavan hazer y sus Altezas, siendo informadas de las tyranias del Comendador Mayor, por las cuales avía merescido la muerte, mandaron que se quedasse el negocio sin más averiguaciones». 
Tras el informe del Juez a los monarcas, el rey escucha la versión de boca de los propios vecinos, de la tiranía del Comendador y como broche final apelan a su jurisdicción, con lo que implícitamente quieren manifestar su intención de desvincularse de la Orden:

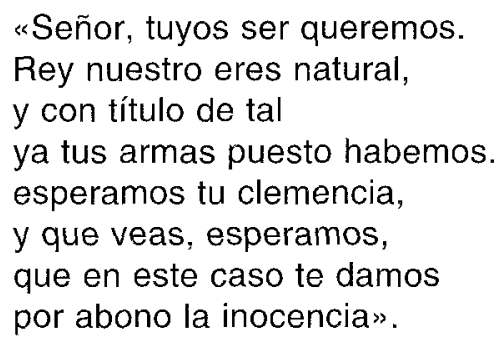

En el fallo absolutorio inmediato del rey algunos autores han querido ver una maniobra política en interés del propio monarca de hacerse adeptos ante el peligro que suponía el poder de las Ordenes Militares, pués ya se venía perfilando el final de éstas, que acaecería veinte años mas tarde, cuando los propios monarcas acordaron la anexión de los maestrazgos a la Corona. Así el rey en la sentencia dada, no solo acuerda la absolución de los vecinos de Fuente Ovejuna por el delito cometido, sino que atrae para así la jurisdicción de la villa:

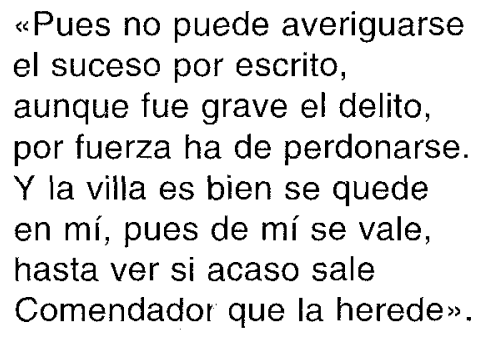

Algunos autores, basados en las crónicas de la época contrarias a los intereses políticos del monarca han querido ver en esta absolución y simultanea atracción de la jurisdicción una especie de contraprestación por aquella «y la villa es bien se quede /en mí, pues de mí se vale».

\section{B) El proceso civil}

Como ya vimos anteriormente, la cuestión civil relativa a la jurisdicción de la villa de Fuente Ovejuna data de 1460 cuando el monarca reinante, 
Enrique IV, hace donación de dicha villa a D. Pedro Girón, Maestre de Calatrava y cuando, posteriormente, en 1462 le es otorgada licencia para cambiarla por las de Osuna y Cazalla, propiedad de la Orden que presidía, al propio tiempo que se otorgaba a Fuente Ovejuna el privilegio de independencia, eximiéndola del dominio que hasta entonces habia ejercido sobre ella la ciudad de Córdoba, lo que hizo nacer la hostilidad de esta última frente al arrebato de estas posesiones. Finalmente la Orden de Calatrava toma posesión de la villa en el año 1468.

De la lectura de la obra no se infiere ningún resultado de la cuestión civil dimanante de la Comisión dada al Juez pesquisidor, sin embargo, ésta se dilató mucho en el tiempo, pues la sentencia que pondría fin al procedimiento civil, no recaería hasta 1513 , ya bajo el reinado de Doña Juana, hija de los Reyes Católicos.

De la lectura detallada de la Comisión dada por los Reyes al Juez Pesquisidor, que en el epígrafe anterior ha sido transcrita, se pueden destacar las siguientes notas, relativas a cuestiones procesales meramente civiles:

- Se establece el derecho de los villanos a ser oídas («que guardáredes nuestro servicio e el derecho de las partes").

- Le encargan el embargo y retención de los bienes que fueron del Comendador y que le fueron saqueados por los villanos, y ponerlos en depósito, bajo inventario, y con intervención de notario, en manos de buenas personas («todos los bienes e otras cosas que halláredes del dicho Comendador, los saquedes del poder de quien los halláredes... e los pongades en poder de buenas personas, llanas e abonadas, por inventario ante escrivano público...).

- La restitución de dichos bienes a los criados del Comendador, sin cargo alguno ( «de todos los bienes que halláredes de los criados e escuderos... Ios fagais luego restituir e entregar libremente, sin contra alguna").

- El pago, tanto de las costas del proceso como de los honorarios del Juez enviado, serán a cargo de los bienes del Comendador, durante el plazo que se le concede para sus pesquisas - sesenta dias- («para vuestro salario e mantenimiento de sesenta dias... os sean pagados de los bienes del Comendador Mayor de los quales os podais entregar por vuestra propia autoridad").

- Mandato de auxilio judicial en la practica de las gestiones encomendadas: ( E mandamos al Concejo, Alcaldes e Alguacil, Regidores, Oficiales e omes buenos de la dicha villa de Fuente-Ovejuna e a otros cualesquier Concejo, justicias de sucomarca, e a cada uno de ellos que os den e hagan dar todo el favor e ayuda que les pidiéredes") ) 
Aunque pudiera interpretarse que la investigación judicial ha dado por concluida, es lo cierto que los Reyes Católicos, a petición de D. Juan de Guzmán, hermano del Comendador ajusticiado, el 18 de febrero de 1477 dirigen una carta al Marqués de Cádiz para que dé ayuda a los jueces nombrados para investigar los hechos acaecidos en Fuenteovejuna, de donde se infiere que hubo, al menos, otra designación de juez pesquisidor. Dicha carta sería como a continuación se transcribe (Archivo General de Simancas, Registro General, folio 293):

«Don Fernado e Doña Isabel... a vos, D. Rodrigo Ponce de León, Marqués de Cádiz, Conde de Carcos, del nuestro Concejo, salud e gracia. Sepades que Juan de Guzman, nuestro vasallo e del nuestro Concejo, cuya es la villa de Teba, nos fizo relación por su petición diziendo que por causa que el Concejo, vecino e moradores de la villa de Fuenteobeguna, fueron en matar y mataron a don Fernán Gómez de Guzmán, y en le robar todo lo que tenía en la dicha villa, a él se quejó de ello ante mí, la Reina. Y yo mandé cometer el conoscimiento e ejecución de lo susodicho al Licenciado Juan Sánchez de Gallegos e al bachiller Luis Sánchez e a Vasco Mosquera según más largamente en la dicha carta de comisión se contiene. E dice que agora se teme e recela que, como-quier que los dichos jueces conocerán de la dicha causa y procederán en ella según hallaren por derecho, dice que no podrán ejecutar en los dichos delinquentes e en sus bienes las penas en que cayeron e incurrieron por cometer el dicho delito, en lo qual dice que si asi hubiese apaño, rescibiría grande agravio y daño. $Y$ nos suplicó e pidió por merced cerca de ello con remedio de justicia para que por la ejecución de lo susodicho, diésedes y ficiésedes dar a los dichos jueces todo favor e ayuda. Lo qual por nos visto, porque nuestra merced e voluntad es que tan feo y enorme caso como éste sea punido y castigado por justicia, porque a éstos sea castigado e a otros ejemplo e se non atrevan de faceerlo tal, mandamos dar esta nuestra carta para vos, por la qual os mandamos que cada $e$ quando fuéredes requerido por los dichos jueces o por qualquier de ellos, que les dedes e fagades dar todo favor y ayuda que necesario avrán para la ejecución de lo que asi pronunciaren por virtud de la dicha carta de comisión, que por vuestra persona e con vuestras gentes e armas se lo dedes e fagades dar, por manera que la sentencia que en dicha razón diere e pronunciare, será traída e deriva ejecución con efecto tanto quanto de derecho se requiera, e para ello vos juntedes poderosamente con esos dichos juezes 0 con cualquier de ellos. E non fagades ende al por quanto asi cumple a nuestro servicio. Toledo, diez e ocho de fevrero anno de mill quatrocientos setenta e siete».

Del examen de este documento se desprende:

- La duda de los Reyes Católicos sobre la transparencia de la investigación judicial: "se teme e recela que, como-quier que los dichos jueces conocerán en la dicha causa y procederán en ella según hallaren por derecho, dice que no podrán ejecutar en los dichos delinquentes». Ello supone ya la 
emisión de un juicio de valor, al referirse a los villanos de Fuenteovejuna como «delinquentes»

- Nueva exposición del criterio de los reyes sobre la culpabilidad en el suceso: «lo qual por nos visto porque nuestra merced e evoluntad es que tan feo y enorme caso como este sea punido y castigado por justicia, porque a éstos sea castigado e a otros ejemplo e se non atrevan a facerlo tal». Además se aprecia un ánimo ejemplificador en el castigo, pretendiendo la prevención de otros intentos similares

- Tienen temor al arraigo en la insurreción

El 24 de marzo de 1477 los Reyes Católicos envían una carta al Concejo y Vecinos de la villa de Fuenteovejuna, para que entreguen dicha villa al Licenciado Fernando Yáñez Lobón, Alcalde de Casa y Corte del Consejo Real, para que la tenga en secuestración hasta que se decida si pertenece a la ciudad de Córdoba o al Maestre y Orden de Calatrava (Archivo General de Simancas, Registro General del Sello - 1477- folio 409):

Don Fernando e Doña Isabell Bien sabedes en como por otras nuestras cartas, firmadas de nuestro nombre e selladas con nuestro sello, os hubimos enviado mandar que por algunas causas asi complideras a nuestro servizio, e al bien, pacificación e sosiego de esta tierra, diésedes e entregásedes esa dicha villa, con la jurisdiccion cevil e criminal, rentas, pechos, e derechos de ella, e la pusiéredes en poder del doctor Alfonso Manuel, oidor de la nuestra audiencia e de nuestro Consejo, para que él tuviese la dicha villa con las cosas ya dichas en secuestración e de manifiesto, hasta tanto que nos mandásemos ver e fuese vista la justicia que al señorio de esta dicha villa el Maestre e Orden de Calabrava pretenden, con otras coas que más por extenso en las dichas nuestras cartas se contiene, cono las quales, comoquiera que fuisteis requeridos, no lo habeis querido ni queredes fazer, e por ella habeis incurrido en graves penas, las quales nos con juntas razón podiamos mandar ejecutar en vosotros, pero por vos más convencer, mandamos dar e damos esta nuestra carta para vosotros en la dicha razón, por la qual os mandamos... dedes e entreguedes e hagades luego dar a entregar esa dicha villa de Fuente-obejuna al licenciado Fernán Yáñez Lobón... que es nuestra merced e voluntad que la tenga en secuestración hasta que sea por nos vista la justicia del dicho Maestre e Orden, e mandado lo que cerca de ellos se haya de fazer, e durante el tiempo que asi la tuviere en la dicha secuestración, la dejedes e consintades a él, o al que por su poder hubiere, libremente usar de la justicia alta e baja, mero e mixto imperio, de la dicha villa, e le recudiedes e fagades recudir con las rentas, pechos e derechos e otras coas que esa dicha villa rentare o recudiere e también las que son anexas e pertenecientes al señorio de ella, para que todo ello lo tenga en la dicha sesucestración e de manifiesto para recudir cono ella a quien por derecho se fallare a nuestra mere fuera. A qual dicho licenciado Fernando Yáñez nuestro alcalde, mandamos e damos por él cumplido para que tome e reciba esta dicha villa en la dicha secuestración e use de la justicia e juris- 
dicción de ella e cobre las dichas rentas e pechos e derechos para la tener en la dicha secuestración e de manifiesto hasta que lo susodicho sea visto por la justicia como dicho es. E los unos e los otros non fagades ende por alguna manera, so pena de la noestra merced e de privación de los oficios e de confiscación de los bienes de los que lo contrario facieren para nuestra cámara. De los quales dichos oficios vosotros, lo contrario faziendo, por la presente os suspendemos e avemos por suspendidos. Madrid, veinte e quatro dias del mes de marzo, anno de mill e quatrozientos setenta y siete.

- Se pone de manifiesto que los Reyes Católicos conocían a D.Rodrigo Téllez Girón (quien ya se había reconciliado con ellos tras participar en la toma de Ciudad Real a favor de la causa del rey de Portugal), quien pretendía la vuelta de la villa de Fuente Ovejuna a la jurisdicción de la Orden de Calatrava «hasta tanto nos mandásemos ver e fuese vista la justicia que al sñorío de esta dicha villa el Maestre o la Orden de Calatrava pretenden".

- La contienda sobre la jurisdicción de Fuente Ovejuna es decisión real: "Os mandamos dedes e entreguedes e hagades luego dar y entregar esa dicha villa de Fuente-Obejuna al Licenciado Fernán Yañez de Lobón, que es nuestra merced e voluntad que la tenga en secuestración hasta que sea por nos vista la justicia del dicho Maestre e Orden e mandado lo que cerca de ellos e haya de fazer'».

- El depósito y retención de las rentas producidas por la vista hasta que se decida la titularidad de la villa "para que todo ello lo tenga en la dicha secuestración e de manifiesto para recudir con ella a quien por derecho se fallare a nuestra merced fuera».

- Nuevo apercibimiento a los vecinos de Fuenteovejuna para el caso de incumplimiento de lo dispuesto por los Reyes Católicos en la mencionada carta: " de los quales dichos oficios vosotros, lo contrario faziendo, por la presente os suspendemos e avemos por suspendidos".

El 1 de septiembre de 1477 la Reina Isabel dirige una carta al juez comunicándole la atribución a la jurisdicción real de la causa seguida a los vecinos de Fuente Ovejuna por la muerte del Comendador (Archivo de Simancas, Registro General del Selo, 1477, folio 502):

"Doña Isabel... a vos el licenciado Gallegos, e a vos e a cada uno e qualquier de vos a quien esta mi carta fuere mostrada, salud e gracia. Bien sabeis como yo os hube mandado cometer e cometí por una mi carta de comisión, cierto delito que por los vecinos e moradores de fuenteobejuna e por ciertas personas singulares de ella, fue fecho al tiempo que el comendador Mayor de la Orden de Calatrava fue muerto en la dicha villa, para que viésedes la justicia, e llamadas e oidas las parrtes, ejecutásedes e hiciésedes ejecutar... en los delinquentes...E agora sabed que por algunas causas e razones que a ello me mueven complideras a mi servicio e a la ejecución de mi 
justicia, mi merced e voluntad es de advocar e por esta mi carta advoco a mi el dicho pleito e negocio para que en el mi Concejo se vea determine la justicia, e de vos inhibir e por la presente os inhibo del conocimiento de ella, porque os mando por esta mi carta fuéredes requerido, non conoscais nin os entremetais más de conocer del dicho pleito o negocio nin de hacer nin proceder en la cosa alguna mas de lo que ahi habeis hecho e procedido, salvo que los remitades a los de mi Concejo en el estado en el que agora está.... Sevilla, uno de septiembre del anno de mill juatrocientos e setenta e siete".

- Aparece la figura de la advocación (atracción por parte de un orden jurisdiccional jerárquicamente superior de la competencia de una causa o procedimiento que está conociendo otro de naturaleza inferior). En virtud de ésta, releva al Juez del nombramiento y de toda actuación posterior, considerando "entrometimiento" cualquier acto que no sea la remisión de lo actuado al Consejo Real.

El proceso continúa y se suceden nuevas órdenes reales, como la Carta dada al Concejo y vecinos de la villa de Fuente Ovejuna el 3 de octubre de 1477, en el mismo sentido de otras anteriores, para que restituyan los bienes a sus legítimos propietarios, que ya lo eran antes de la usurpación por parte del Comendador de Calatrava.

La respuesta a estas cartas por parte de los vecinos es la de pasividad, pues ni ejecutan dicha orden ni aducen ningún derecho para lo contrario. En definitiva, toman una actitud de desentendimiento del Derecho.

Se observa durante este proceso un cambio en la actitud pasiva de los reyes, en cuanto a la jurisdicción de Fuente Ovejuna y la contienda entre Córdoba y la Orden de Calatrava, que habían mantenido hasta la advocación de la causa a la jurisdicción real. Y ello en base a que las partes contendientes ya habian obtenido decisiones eclesiásticas al respecto, cuya desobediencia acarreaba la excomunión. Así los Reyes, como buenos católicos, en sus decisiones se limitan a secularizar los mandatos eclesiásticos.

Para cumplimiento de lo mandado en una Bula papal de Paulo II, en la que se ordena restituir la villa de Fuente Ovejuna y todos sus bienes enajenados, a la Orden de Calatrava, la reina da una provisión a petición del Maestre para hacer cumplir dicha bula.... »el dicho juez apostólico por virtud del dicho rescrito e comisión apostólica, procedió, llamadas y oidas las partes por su sentencia declaró a la dicha ciudad de Córdoba e vecinos de Fuenteobejuna, e personas en el dicho proceso nombradas, ser tenidos e obligados a restituir al dicho Maestre e a su Orden la posesión de la dicha villa con todo lo susocicho...”

Visto que ni en los distintos procedimientos judiciales incoados, ni en las distintas jurisdicciones conocedoras de ellos, fueron capaces de resolver la 
controversia suscitada, pues se sucedieron pronunciamientos, en algunas ocasiones favorables a la Orden de Calatrava y a la ciudad de Córdoba, en otras, siendo sistemáticamente unos y otros incumplidos, el pleito civil se prolongó, tras una fase en la que la competencia fue de la jurisdicción eclesiástica, hasta el año 1513, cuando la reina Doña Juana, sucesora de los Reyes Católicos, advocó nuevamente a la jurisdicción real y dictó sentencia definitiva por la cual se restituyó el señorío sobre la villa de Fuente Ovejuna a la ciudad de Córdoba, decretándose indemnización a la Orden de Calatrava que hubieron de satisfacer tanto la mencionada ciudad de Córdoba como la propia Corona.

\section{BIBLIOGRAFIA}

BAENA, J.: «Tener Voz y dar voces en una audiencia: dos discursos procesales». Bulletin of the Comediantes. 42.1, 1990 (págs. 143 a 154).

Cabrera Muñoz, E. y Moro, A.: Fuenteovejuna: La violencia antiseñorial en el siglo XV». Barcelona, 1991.

García Aguilera y Hernández Osorno: Revuelta y litigios de los villanos de la Encomienda de Fuenteobejuna.

GarRiga, C.: La Audiencia y Chancillerias castellanas (1371-1525). Centro de Estudios Constitucionales.

Gómez Moriana: Derecho de resistencia y tiranicidio. Estudio de una temática en las comedias de Lope de Vega. Santiago de Compostela, 1968.

LALINDE ABADIA: Iniciación ristórica al Derecho español.

LOPEZ DE Vegga: Fuente Ovejuna. Ed. Espasa Calpe, 1995.

RAmírez dE ARELLANO: «Rebelión en Fuente Ovejuna contra el Comendador de Calatrava D. Fernán Gómez de Guzmán». Boletín de la Real Academia de la Historia 34, 1901.

RODRíguez FloRES: El perdón real en Castilla: siglos XIII a XVII. Universidad de Salamanca, 1971.

VILlapalos Salas: Justicia y Monarquía: Puntos de vista sobre su evolución en el reinado de los Reyes Católicos. Ed. Pons, 1997. 